\title{
The Influence of Land Use and Rainfall on Shallow Landslides in Tanralili Sub-watershed, Indonesia
}

\section{Hasnawir}

Laboratory of Forest Conservation and Erosion Control, Department of Agro-environmental Sciences, Faculty of Agriculture Kyushu University | Environment and Forestry Research and Development, Institute of Makassar, Ministry of Environment and Forestry of Indonesia

\section{Kubota, Tetsuya}

Laboratory of Forest Conservation and Erosion Control, Department of Agro-environmental Sciences, Faculty of Agriculture, Kyushu University

\section{Sanchez-Cast illo, Laura}

Laboratory of Forest Conservation and Erosion Control, Department of Agro-environmental Sciences, Faculty of Agriculture Kyushu University | Department of Forest and Biomaterial Sciences, Faculty of Agriculture, Kyoto University : Research Fellow

\section{Soma, Andang Suryana}

Graduate School of Bioresource and Bioenvironmental Laboratory of Forest Conservation and Erosion Control, Department of Agro-environmental Sciences, Faculty of Agriculture Kyushu University | Sciences, Faculty of Agriculture, Kyushu University : Graduate Student

https://doi.org/10.5109/1801778

出版情報：九州大学大学院農学研究院紀要. 62 (1)，pp.171-176，2017-02-24. Faculty of Agriculture, Kyushu University バージョン :

権利関係 : 


\title{
The Influence of Land Use and Rainfall on Shallow Landslides in Tanralili Sub-watershed, Indonesia
}

\author{
HASNAWIR $^{1 *}$, Tetsuya KUBOTA ${ }^{2 *}$, Laura SANCHEZ-CASTILLO ${ }^{3}$ \\ and Andang Suryana SOMA ${ }^{4}$
}

\author{
Laboratory of Forest Conservation and Erosion Control, Department of Agro-environmental Sciences, \\ Faculty of Agriculture Kyushu University, Fukuoka 812-8581 \\ (Received October 17, 2016 and accepted November 4, 2016)
}

\begin{abstract}
Land cover is an important factor affecting the occurrence of shallow landslides triggered by high intensity rainfall. The objectives of this study are the analyses of the influences of land use and rainfall on shallow landslides using the normalized difference vegetation index (NDVI) and antecedent rainfall threshold. This research was conducted in Tanralili sub-watershed, South Sulawesi Province, Indonesia. The analysis of NDVI using Landsat time series data of 2000, 2003, 2006, 2009, 2011 and 2013. The result indicated that in the course of 14 years high vegetation density land cover (81\% to 100\%) has lost around $24.21 \%$ or 6219 ha. The vegetation density decrease is caused mainly by land use change, especially the conversion of shrubs and forests into mixed dryland farming. $76.67 \%$ of shallow landslides occurred are concentrated in mixed dryland farming on the low vegetation density ( 0 to $40 \%)$. The analysis of the absolute and calibrated antecedent rainfall associated with each major shallow landslide event showed that shallow landslides occurred in short duration (1 day) with a high intensity $225 \mathrm{~mm} /$ day and longer duration (1 month) with a lower intensity $13 \mathrm{~mm} /$ day. The rainfall threshold for shallow landslides in the study area are ruled by the function $\mathrm{I}=$ $25.5 \mathrm{D}^{-1.10}$, where I is the average rainfall intensity in $\mathrm{mm} /$ day and $\mathrm{D}$ is duration of rainfall in days.
\end{abstract}

Key words: Land use, Landslides, Rainfall, Indonesia

\section{INTRODUCTION}

Landslides are one of the most frequent disasters in Indonesia. National Disaster Management Agency (2015), reported that in the last 10 years, landslides become the third highest type of disaster after floods and whirlwind. Landslides including shallow landslides occurred on various types of land use and generally occur during the rainy season with high rainfall intensity (Hasnawir and Kubota, 2012).

The influence of land use change on landslide under different geomorphic conditions has been analyzed by researchers taking into account different methods (Pande et al., 2002), including historical archives (Glade, 2003), aerial photographs interpretation ( $\mathrm{Su}$ and Stohr, 2000), susceptible mapping, multivariate statistical analyses, laboratory and field investigations (Gerrard and Gardner, 2002), modeling (Abe and Ziemer, 1991; Montgomery et al., 2000; Van Beek and Van Asch, 2004), geographical information systems (Temesgen et al., 2001), remote sensing (De La Ville et al., 2002), and diachronic analy-

Environment and Forestry Research and Development Institute of Makassar, Ministry of Environment and Forestry of Indonesia, Makassar 90243

2 Laboratory of Forest Conservation and Erosion Control, Department of Agro-environmental Sciences, Faculty of Agriculture, Kyushu University, Fukuoka 812-8581

Research Fellow, Department of Forest and Biomaterial Sciences, Faculty of Agriculture, Kyoto University, Kyoto 6068502

${ }^{4}$ Graduate Student, Graduate School of Bioresource and Bioenvironmental Sciences, Faculty of Agriculture, Kyushu University, Fukuoka 812-8581

* Corresponding authors (E-mail: wirforest@yahoo.com, kubot@agr.kyushu-u.ac.jp) sis (Alcantara-Ayala et al., 2006). Land use change is also recognized as an important factor influencing landslides (e.g. Cruden and Varnes, 1996; Fell et al., 2008; Wasowski et al., 2010; Gioia et al., 2015).

The influence of rainfall on landslides differs substantially depending upon landslide dimensions, kinematics, material involved, etc. Shallow failures are usually triggered by short intense storms (Campbell, 1975; Wieczorek, 1987; Polloni et al., 1992; Crosta, 1998; Paronuzzi et al., 2002; Sanchez-Castillo et al., 2015) while most deep-seated landslides are affected by longterm variation of annual rainfall which has to last several years (Bonnard and Noverraz, 2001). For landslides such as rockfalls, no precise correlation with rainfall can be surmised, as they appear more sensitive towards other factors such as chemical-mechanical weathering of the rockmass and temperature fluctuation across the freezing point (Sandersen et al., 1996): only late spring and summer rockfalls can be related with rainfall (Aleotti, 2004). Rainfall thresholds are useful to establish an early warning system for landslide disaster prevention but a proper early warning system must have strong meteorological information, hydrogeological and geotechnical components (Ibsen and Casagli 2004, Guzzetti et al., 2007; Hasnawir and Kubota, 2008, Baum et al., 2010). Several investigators have attempted to determine rainfall amounts responsible for triggering sediment-related disasters establishing rainfall thresholds. Caine (1980) first established worldwide rainfall intensity-duration threshold values for landslides. Recently, Ma et al. (2015) studied rainfall thresholds for landslide activity in Zhejian Province, China and Nolasco-Javier et al. (2015) in Baguio, Philippines.

Therefore, the objectives of this study are the analy- 
ses of the influence of land use and rainfall on shallow landslides using analysis normalized difference vegetation index (NDVI) and antecedent rainfall threshold with data from 2000 to 2013 in Tanralili sub-watershed, Indonesia.

\section{MATERIALS AND METHODS}

\section{Study area}

Tanralili sub-watershed is located at $5^{\circ} 0^{\prime}-5^{\circ} 12^{\prime}$ South latitude and $119^{\circ} 34^{\prime}-119^{\circ} 56^{\prime}$ East longitude on South Sulawesi Province, Indonesia. The area of the subwatershed is about 25684 ha (Fig. 1). The geology is composed of lava (8679 ha or $33.79 \%$ ), Camba formation (23.42\% or 6016 ha), volcanic rocks (17.96\% or 4613 ha) and another geology is breccias, basalt dikes, sediment stoppers, and rocks of Tonasa formation (24.83\%). Type of soil in Tanralili sub-watershed consists of dystropepts (92.40\%), rendolls (5.51\%) and trapaquepts (2.09\%). Regarding land use in Tanralili sub-watershed, $60.93 \%$ of the land use is mixed dryland farming, $22.65 \%$ is forest, $6.82 \%$ is paddy field, $6.05 \%$ is settlement, $2.61 \%$ is shrubs, 0.87 is savanna, and $0.07 \%$ is lake/river. The average annual rainfall is about $3215 \mathrm{~mm} /$ year (2000 to 2013) with high intensity rainfall occurring in December, January, February and March (Fig. 2).

\section{Methods}

The influence of land use and rainfall on shallow landslide in Tanralili sub-watershed using analyses of normalized difference vegetation index (NDVI) and ante-

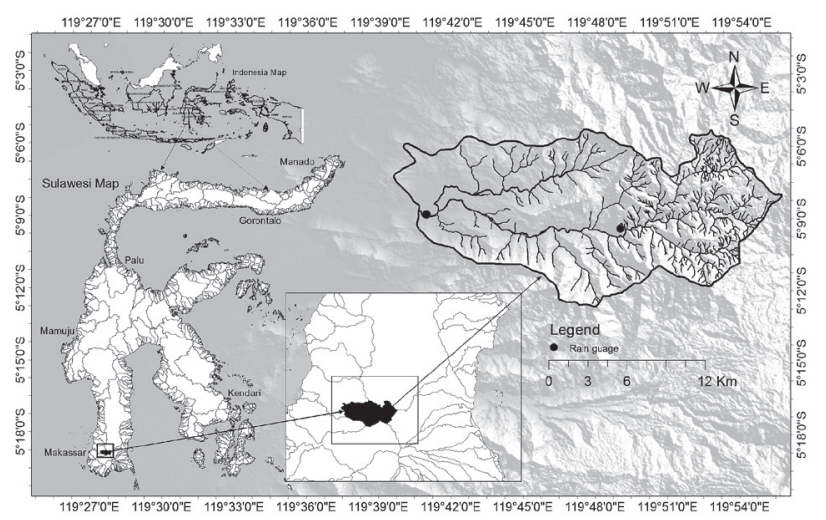

Fig. 1. Location map of study area in Tanralili sub-watershed, South Sulawesi, Indonesia.

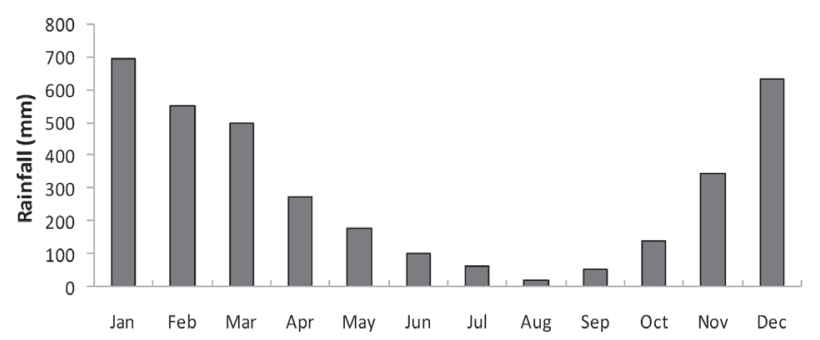

Fig. 2. The monthly rainfall of Tanralili sub-watershed, South Sulawesi, Indonesia (2000-2013). cedent rainfall threshold is conducted.

- Normalized difference vegetation index (NDVI) calculation

NDVI method is used for the interpretation of vegetation density to find the influence of land use on shallow landslides. Landsat data time series used is Landsat time series data of 2000, 2003, 2006, 2009, 2011 and 2013.

Vegetation indices derived from satellite images have been extensively utilized to monitor vegetation and land use changes, particularly NDVI. This index is a function of red and near-infrared spectral bands which depends on the type of sensor (Alcantara-Ayala et al., 2006). The formula of NDVI as follows:

$$
N D V I=\frac{N I R-R}{N I R+R}
$$

where NIR is the near IR band, and R is the red band. The values for NDVI are obtained from SPOT image. Vegetation density classification using Arc GIS spatial analyst at 10.1 .

- Rainfall thresholds and antecedent rainfall analysis Rainfall thresholds

In this study empirical threshold was used. The empirical thresholds refer to relational values based on statistical analysis of the relationship between rainfall and landslide occurrences (Aleotti, 2004). The empirical threshold was studied by applying the intensity-duration (ID) threshold methodology developed by Caine (1980). The ID threshold assumes the general form of the following equation:

$$
I=c+\alpha \times D^{-\beta}
$$

where I is the rainfall intensity (in $\mathrm{mm}$ day $^{-1}$ ), D is the rainfall duration (in day), and $c, \alpha$, and $\beta$ are empirical parameters of the specific site conditions.

Antecedent rainfall

The shallow landslide events used in this study were collected from historical accounts, technical-scientific documents and regional reports. Based on field survey and information from the local people, the shallow landslides have occurred for more than ten years in the study area. Twenty major rainfall episodes that triggered shallow landslides were identified.

Hence the computation analysis of cumulative absolute rainfall for $1,2,3,5,10,15$ and 30 consecutive days before each shallow landslide events during 2000 to 2013 have been carried out by applying equation Marques et al. (2008).

$$
P \mathrm{x}=P 1+P 2+\cdots P \mathrm{n}
$$

where $\mathrm{Px}$ is the absolute antecedent rainfall for day $\mathrm{x}$; $\mathrm{P} 1$ is the daily rainfall for the day before $\mathrm{x}$; $\mathrm{Pn}$ is the daily rainfall for the nth day before day $\mathrm{x}$.

In order to account for this dampening effect in rainfall-shallow landslide analysis, the antecedent rainfall was calibrated applying the formula proposed by Crozier (1986). 


$$
C A R X_{n}=K P 1+K^{2} P 2+\cdots K^{n} P n
$$

where CARXn is the calibrated antecedent rainfall for day $\mathrm{x}$; P1 is daily rainfall for the day before $\mathrm{x}$; $\mathrm{Pn}$ is the daily rainfall for nth day before $\mathrm{x}$. The constant $\mathrm{K}$ is an empirical parameter (typical value range between 0.8 and 0.9) depending on the draining capacity and hydrological characteristics of the area (Capecchi and Focardi, 1988). After a few tentative trials we have decided to assume in this study that $\mathrm{K}=0.9$, making negligible precipitation occurred 30 days before a shallow landslide event. A good assumption of this $\mathrm{K}$ value can be 0.9 for a maximum of 30 antecedent days (Marques et al., 2008; Khan et al., 2012).

\section{RESULTS AND DISCUSSION}

\section{Land use and shallow landslide}

Thirty shallow landslides occurred in Tanralili subwatershed from 2000 to 2013. Regarding to the land use, the shallow landslide occurrence was observed 23 times in mixed dryland farming, 4 in primary forest, 2 in secondary forest, and 1 time in savanna. The significant impact of land use change from 2000 to 2003 in Tanralili sub-watershed was an increase of land without vegetation cover around $21.30 \%$ (Table 1 and Fig. 3). Changes in land use that quite clearly can be attributed to the occurrence of shallow landslides in Tanralili sub-watershed in where the number of shallow landslides increased after 2003. Furthermore, in 2000 land cover with high vegetation density between $81 \%$ to $100 \%$ is around 8548 ha or about $33.28 \%$ from the total area of Tanralili subwatershed. However, after 13 years, high vegetation density decreased to only 2329 ha or $9.07 \%$. This shows that there has been a loss of high vegetation density around $24.21 \%$ or 6219 ha. The vegetation density decrease is caused mainly by the land use change, especially shrubs and forests into mixed dryland farming. It is also causes about $76.67 \%$ of shallow landslides concentrated in mixed dryland farming (Fig. 4). The decreased level of vegetation density is an important factor influencing the incidence of shallow landslides. It is seeming from the concentration of shallow landslides that generally they tend to occur on land with low vegetation density (0 to 40\%) (Fig. 5). Glade (2003) indicates that the land use change is an important factor in the occurrence and movement of rainfall triggered landslides and the occurrence of landslides is directly related to variation in land use. In other study in the Sierra Norte, Mexico it is implied that landsliding is a consequence of the reduction in the density of vegetation, which in many instances resulted in bare surfaces (Alcantra-Ayala, et al., 2006).

\section{Rainfall and shallow landslide}

Twenty rainfall events resulted in thirty shallow landslides in Tanralili sub-watershed in the period 2000 to 2013. There are not any reports or information about shallow landslide before 2000 .

Table 1. Classification of vegetation density in Tanralili sub-watershed, Indonesia (2000-2013)

\begin{tabular}{|c|c|c|c|c|c|c|c|c|c|c|c|c|}
\hline \multirow{2}{*}{$\begin{array}{l}\text { Vegetation Density } \\
(\%)\end{array}$} & \multicolumn{2}{|c|}{2000} & \multicolumn{2}{|c|}{2003} & \multicolumn{2}{|c|}{2006} & \multicolumn{2}{|c|}{2009} & \multicolumn{2}{|c|}{2011} & \multicolumn{2}{|c|}{2013} \\
\hline & ha & $\%$ & ha & $\%$ & ha & $\%$ & ha & $\%$ & ha & $\%$ & ha & $\%$ \\
\hline 0 & 170 & 0.66 & 5650 & 22.00 & 4257 & 16.57 & 4009 & 15.61 & 2223 & 8.66 & 514 & 2.00 \\
\hline $1-20$ & 1184 & 4.61 & 2306 & 8.89 & 2745 & 10.69 & 4251 & 16.55 & 4410 & 17.17 & 2074 & 8.08 \\
\hline $21-40$ & 5275 & 20.54 & 5597 & 21.79 & 5886 & 22.92 & 6218 & 24.21 & 6189 & 24.10 & 2584 & 10.06 \\
\hline $41-60$ & 3842 & 25.95 & 4947 & 19.26 & 5401 & 21.03 & 5216 & 20.31 & 6671 & 25.97 & 10168 & 39.59 \\
\hline $61-80$ & 6665 & 33.28 & 6329 & 24.64 & 6203 & 24.15 & 5239 & 20.40 & 4862 & 18.93 & 8015 & 31.21 \\
\hline $81-100$ & 8548 & 33.28 & 855 & 3.33 & 1192 & 4.64 & 751 & 2.92 & 1329 & 5.17 & 2329 & 9.07 \\
\hline Total & 25684 & 100.00 & 25684 & 100.0 & 25684 & 100.0 & 25684 & 100.0 & 25684 & 100.0 & 25684 & 100.0 \\
\hline
\end{tabular}

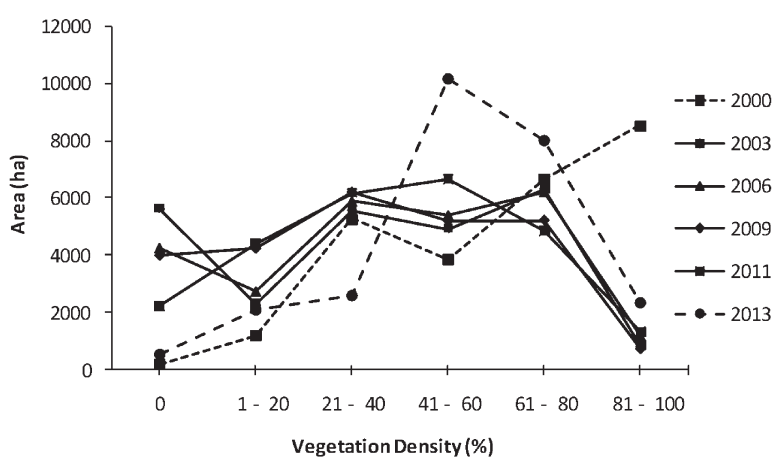

Fig. 3. The vegetation density (\%) with area (ha) in Tanralili sub-watershed, Indonesia (2000-2013).

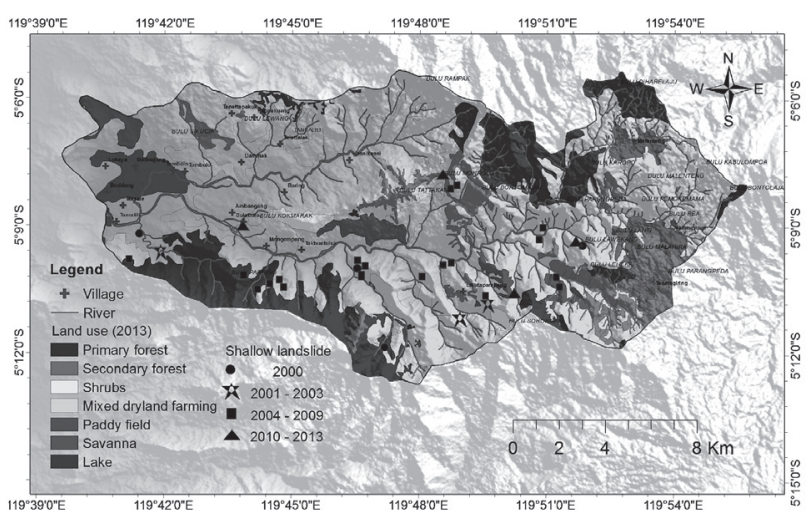

Fig. 4. Shallow landslides and land use in Tanralili sub-watershed, Indonesia (2000-2013). 


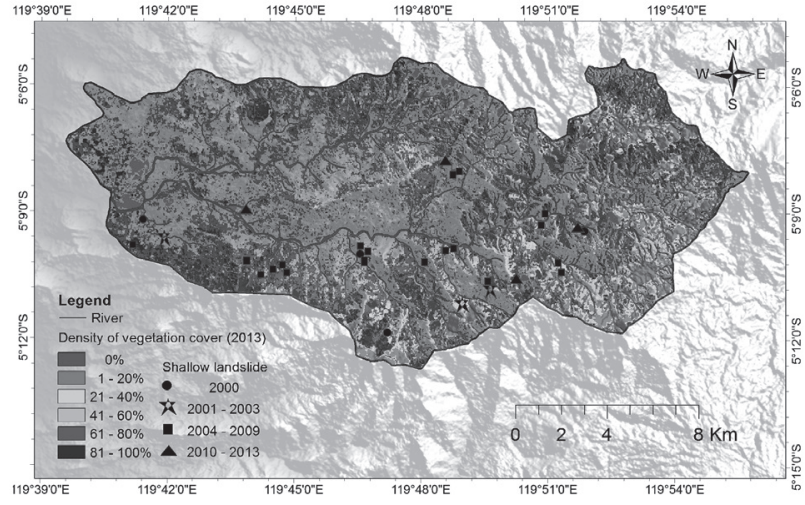

Fig. 5. Shallow landslides and vegetation density in Tanralili subwatershed, Indonesia (2000-2013).

Table 2 summarizes absolute antecedent rainfall for shallow landslide events. The rainfall conditions are traced by shallow landslide activity triggered by short and long episodes of rainfall accumulation. Important shallow landslide took place on January 11, 2004, and this event had the highest rainfall intensity $(250 \mathrm{~mm} /$ day $)$. Few days before the shallow landslide occurrence there were high intensity of rainfall events. Five shallow landslides occurred in that day and resulted in many damages along the local roads. In the same time there was flood disaster in the Tanralili sub-watershed. Another important shallow landslide event in February 29, 2005, there is no rain recorded at least 2 days before the shal-

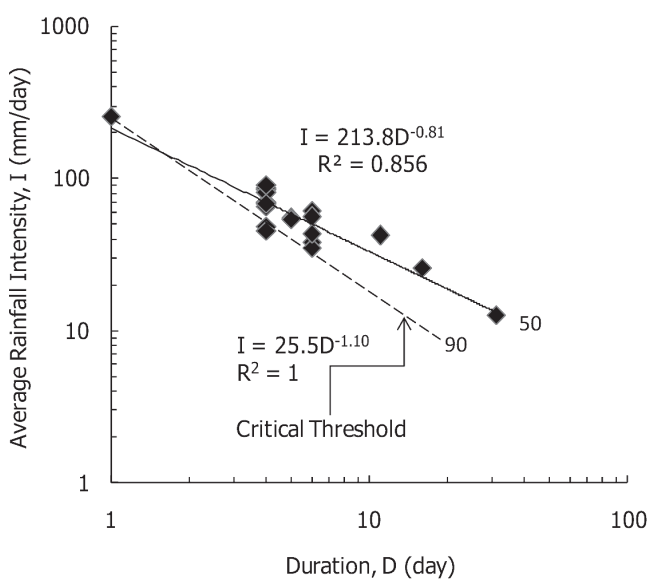

Fig. 6. Rainfall thresholds for shallow landslide in Tanralili sub watershed from 2000 to 2013. Line [90] represents the triggering threshold; the other limit [50] represents different percentage of points in the graph.

low landslide and the daily rainfall intensity was $225 \mathrm{~mm} /$ day. The shallow landslide on February 29, 2005 is the largest shallow landslide during 2000 to 2013 producing a volume of $2400 \mathrm{~m}^{3}$ of sediment. Table 3 summarizes results of calibrated antecedent rainfall for shallow landslide events.

The regression value of rainfall thresholds for shallow landslide (line [90]) was $\mathrm{I}=25.5 \mathrm{D}^{-1.10}$, where $\mathrm{I}$ is the average rainfall intensity in $\mathrm{mm} /$ day and $\mathrm{D}$ is duration of

Table 2. Absolute antecedent rainfall from 1 to 30 days corresponding to shallow landslide events in Tanralili sub-watershed, Indonesia (2000-2013)

\begin{tabular}{|c|c|c|c|c|c|c|c|c|c|}
\hline No & Date & $\begin{array}{l}1 \text { day } \\
(\mathrm{mm})\end{array}$ & $\begin{array}{l}2 \text { days } \\
(\mathrm{mm})\end{array}$ & $\begin{array}{c}3 \text { days } \\
(\mathrm{mm})\end{array}$ & $\begin{array}{l}5 \text { days } \\
(\mathrm{mm})\end{array}$ & $\begin{array}{c}10 \text { days } \\
\text { (mm) }\end{array}$ & $\begin{array}{c}15 \text { days } \\
\text { (mm) }\end{array}$ & $\begin{array}{c}30 \text { days } \\
(\mathrm{mm})\end{array}$ & $\begin{array}{c}\text { Rainfall Intensity } \\
\text { (mm/day) }\end{array}$ \\
\hline 1 & Feb. 03, 2000 & 6 & 45 & 78 & 126 & 182 & 207 & 229 & 200 \\
\hline 2 & Mar. 03, 2000 & 37 & 48 & 67 & 107 & 204 & 224 & 278 & 122 \\
\hline 3 & Mar. 04, 2001 & 24 & 38 & 78 & 88 & 109 & 147 & 184 & 261 \\
\hline 4 & Dec. 28, 2002 & 6 & 36 & 58 & 79 & 121 & 163 & 193 & 200 \\
\hline 5 & Jan. 13, 2003 & 12 & 67 & 129 & 216 & 289 & 309 & 352 & 150 \\
\hline 6 & Jan. 11, 2004 & 12 & 28 & 52 & 72 & 98 & 197 & 358 & 140 \\
\hline 7 & Jan. 25, 2004 & 18 & 62 & 97 & 132 & 148 & 213 & 281 & 250 \\
\hline 8 & Feb. 04, 2004 & 43 & 84 & 102 & 153 & 206 & 283 & 329 & 218 \\
\hline 9 & Dec. 19, 2004 & 12 & 38 & 54 & 103 & 148 & 179 & 275 & 200 \\
\hline 10 & Jan. 10, 2005 & 7 & 13 & 18 & 74 & 100 & 154 & 230 & 163 \\
\hline 11 & Feb. 28, 2005 & 0 & 0 & 5 & 33 & 95 & 120 & 195 & 225 \\
\hline 12 & Mar. 12, 2005 & 36 & 67 & 125 & 145 & 163 & 220 & 295 & 135 \\
\hline 13 & Mar. 28, 2006 & 25 & 46 & 78 & 114 & 209 & 320 & 456 & 228 \\
\hline 14 & Feb. 21, 2007 & 11 & 58 & 102 & 173 & 217 & 314 & 520 & 160 \\
\hline 15 & Feb. 02, 2008 & 20 & 78 & 82 & 109 & 287 & 421 & 610 & 172 \\
\hline 16 & Jan. 31, 2009 & 56 & 128 & 204 & 259 & 325 & 524 & 689 & 158 \\
\hline 17 & Jan. 12, 2010 & 34 & 137 & 168 & 197 & 283 & 478 & 679 & 89 \\
\hline 18 & Feb. 28, 2011 & 8 & 12 & 35 & 38 & 43 & 67 & 315 & 125 \\
\hline 19 & Mar. 19, 2012 & 4 & 37 & 47 & 62 & 84 & 198 & 281 & 148 \\
\hline 20 & Jan. 14, 2013 & 2 & 25 & 31 & 63 & 117 & 146 & 198 & 195 \\
\hline
\end{tabular}


Table 3. Calibrated antecedent rainfall (CAR) for shallow landslide events in Tanralili sub-watershed, Indonesia (2000-2013)

\begin{tabular}{rccccccc}
\hline No & Datea & $\begin{array}{c}\text { Daily rainfall } \\
(\mathrm{mm})\end{array}$ & $\begin{array}{c}3 \text { days } \\
(\mathrm{mm})\end{array}$ & $\begin{array}{c}5 \text { days } \\
(\mathrm{mm})\end{array}$ & $\begin{array}{c}10 \text { days } \\
(\mathrm{mm})\end{array}$ & $\begin{array}{c}15 \text { days } \\
(\mathrm{mm})\end{array}$ & $\begin{array}{c}30 \text { days } \\
(\mathrm{mm})\end{array}$ \\
\hline 1 & Feb. 03, 2000 & 200 & 42 & 99 & 181 & 289 & 399 \\
2 & Mar. 03, 2000 & 122 & 72 & 121 & 191 & 312 & 431 \\
3 & Mar. 04, 2001 & 261 & 52 & 109 & 167 & 231 & 309 \\
4 & Dec. 28, 2002 & 200 & 35 & 77 & 129 & 200 & 287 \\
5 & Jan. 13, 2003 & 150 & 65 & 159 & 301 & 471 & 636 \\
6 & Jan. 11,2004 & 140 & 33 & 71 & 119 & 176 & 281 \\
7 & Jan. 25, 2004 & 250 & 66 & 137 & 224 & 311 & 424 \\
8 & Feb. 04, 2004 & 218 & 107 & 181 & 281 & 403 & 554 \\
9 & Dec. 19, 2004 & 200 & 42 & 81 & 149 & 236 & 331 \\
10 & Jan. 10, 2005 & 163 & 17 & 30 & 79 & 138 & 219 \\
11 & Feb. 28, 2005 & 225 & 0 & 4 & 25 & 81 & 145 \\
12 & Mar. 12, 2005 & 135 & 87 & 178 & 273 & 369 & 486 \\
13 & Mar. 28, 2006 & 228 & 60 & 117 & 191 & 315 & 485 \\
14 & Feb. 21, 2007 & 160 & 57 & 131 & 245 & 373 & 540 \\
15 & Feb. 02, 2008 & 172 & 81 & 141 & 212 & 382 & 606 \\
16 & Jan. 31, 2009 & 158 & 154 & 303 & 473 & 665 & 943 \\
17 & Jan. 12, 2010 & 89 & 142 & 264 & 393 & 560 & 814 \\
18 & Feb. 28, 2011 & 125 & 17 & 42 & 67 & 93 & 128 \\
19 & Mar. 19, 2012 & 148 & 34 & 68 & 109 & 158 & 263 \\
20 & Jan. 14, 2013 & 195 & 22 & 45 & 86 & 155 & 233 \\
\hline
\end{tabular}

rainfall in days. This regression is considered as a reliable rainfall threshold for study area, above which, shallow landslide events may occur. In Tanralili sub-watershed shallow landslide occurred in short duration (1 day) with intensity $255 \mathrm{~mm} /$ day, and longer duration (1 month) with a lower intensity 13 mm/day (Fig. 6).

\section{CONCLUSIONS}

Recent observations and reports information showed that shallow landslides are frequent in Tanralili subwatershed, Indonesia. During 14 years the land cover with high vegetation density ( $81 \%$ to $100 \%$ ) had a loss of vegetation density of around $24.21 \%$ or 6219 ha. The vegetation density decrease is caused by land use change, especially of shrubs and forests into mixed dryland farming. $76.67 \%$ of shallow landslides that occurred is concentrated in mixed dryland farming on the low vegetation density (0 to 40\%).

The rainfall conditions are traced by shallow landslide activity triggered by short and long episodes of rainfall accumulation in Tanralili sub-watershed. The shallow landslide occurred in short duration (1 day) with a high intensity $225 \mathrm{~mm} /$ day and longer duration (1 month) with a lower intensity $13 \mathrm{~mm} /$ day. The rainfall threshold for shallow landslides in the study area are rule by the function $\mathrm{I}=25.5 \mathrm{D}^{-1.10}$, where $\mathrm{I}$ is the average rainfall intensity in $\mathrm{mm} /$ day and $\mathrm{D}$ is duration of rainfall in days.

\section{ACKNOWLEDGMENT}

The authors grateful to Meteorological, Climatological and Geophysics Agency and to the National Disaster Management Agency of Indonesia (local agency) for having provided the rainfall data and disaster information.

\section{REFERENCES}

Abe, K and R. R. Ziemer. 1991. Effect of tree roots on a shear zone: modeling reinforced shear stress. Canadian Journal Forest Research 21(7): 1012-1019

Alcantara-Ayala, I., O. Esteban-Chavez and J. F. Parrot. 2006. Landsliding related to land-cover change: A diachronic analysis of hillslope instability distribution in the Sierra Norte, Puebla, Mexico. Catena, 65: 152-165

Aleotti, P. 2004. A warning system of rainfall-induced shallow failure, Engineering Geology, 73: 247-265

Baum, R. L., J. W. Godt and W. Z. Savage. 2010. Estimating the timing and location of shallow rainfall-induced landslides using a model for transient, unsaturated infiltration. Journal of Geophysical Research, Earth Surface. F03013, doi:10.1029/2009JF001321

Bonnard, C and F. Noverraz. 2001. Influence of climate change on large landslides: assement of long term movements and trends. Proceedings of the International Conference on Landslides: Causes Impact and Countermeasures, Gluckauf, Essen, Davos, 121-138

Caine, N. 1980. The rainfall intensity-duration control of shallow landslides and debris flows, Geografiska Annaler, 62A: 23-27

Campbell, R. H. 1975. Debris flow originating from soil slip during rainstorm in southern California. Quarterly Journal of Engineering Geology 7: 377-384

Capecchi F and P. Focardi. 1988. Rainfall and landslides: 
research into a critical precipitation coefficient in an area of Italy. In Landslides, Proceedings of the Fifth International Symposium Landslides, Bonnard C (ed). Balkema: Roterdam; 1131-1136

Crosta G. 1998. Regionalization of rainfall thresholds: an aid to landslide hazard evaluation. Environmental Geology, 35(23): $131-145$

Crozier M. 1986. Landslides: Causes, Consequences and Environment. Croom Helm; London, 252

Cruden, D. M and D.J. Varnes. 1996. Landslides types and processes, in: Landslides Investig. Mitigation, Transp Res. Board Spec. Rep. 247, edited by: Turner, A. K. and Schuster, R. L., National Academy Press, Washington, D. C., 36-72

De La Ville, N., A.C. Diaz and D. Ramirez. 2002. Remote sensing and GIS technologies as tools to support sustainable management of areas devastated by landslides environment. Development and Sustainability, 4(2): 221-229

Fell, R., J. Corominas, C. Bonnard, L. Cascini, E. Leroi and W. Z. Savage, W. 2008. Guidelines for landslide susceptibility, hazard and risk zoning for land use planning, Eng. Geol., 102: $85-98$

Gerrard, J and R. Gardner. 2002. Relationships between landsliding and land use in the Likhu Khola drainage basin, Middle Hills, Nepal. Mountain Research and Development, 22(1): 48-55

Gioia, E., G. Speranza, F. Appiotti, M. Ferretti and F. Marincioni. 2015. Rainfall threshold and landslides in the post-orogenic complex of the Esino River Basin, central Italy, in: vol. 2, Engineering Geology for Society and Territory, 2: 1553-1556

Glade, T., 2003. Landslide occurrence as a response to land use change: a review of evidence from New Zealand. Catena, $\mathbf{5 1}$ (3-4): 297-314

Guzzetti, F., S. Peruccacci, M. Rossi and C. Stark. 2007. Rainfall thresholds for the initiation of landslides in central and southern Europe. Meteorology and Atmospheric Physics, 98: 239267

Hasnawir and T. Kubota. 2008. Analysis of critical value of rainfall to induce landslide and debris-flow in Mt. Bawakaraeng Caldera, South Sulawesi, Indonesia. J. Fac. Agr. Kyushu Univ., 53(2): 523-527

Hasnawir and T. Kubota. 2012. Rainfall thresholds for shallow landslides in Kelara watershed, Indonesia. International Journal of Erosion Control Engineering, 5-1: 86-92

Ibsen, M and L. N. Casagli. 2004. Rainfall patterns and related landslide incidence in the Porretta-Vergato region, Italy Landslides July 2004 1-2: 143-150

Khan, Y. A., H. Lateh, M. Z. Baten and A. A., Kamil. 2012. Critical antecedent rainfall conditions for shallow landslides in Chittagong City of Bangladesh. Environ Earth Sci, 67: 97-106

Ma, T., C. Li, Z. Lu and Q. Bao. 2015. Rainfall intensity-duration thresholds for the initiation of landslides in Zhejiang Province, China. Geomorphology, 245: 193-206

Marques, R., J. Zêzere, R. Trigo, J. Gasparl and I. Trigo. 2008. Rainfall patterns and critical values associated with landslides in Povoação County (São Miguel Island, Azores): relationships with the North Atlantic Oscillation. Hydrological Process, 22: 478-494

Montgomery, D. R., K. M. Schmidt, H. Greenberg and W. E. Dietrich. 2000. Forest clearing and regional landsliding. Geology 28: 311-314

National Disaster Management Agency of Indonesia. 2005

Nolasco-Javier, D., L. Kumar and A. Tengonciang. 2015. Rapid appraisal of rainfall threshold and selected landslides in Baguio, Philippines. Natural Hazards, 78(3): 1587-1607

Pande, A., R. C. Joshi and D. S. Jalal. 2002. Selected landslide types in the Central Himalaya: their relation to geological structure and anthropogenic activities. Environmentalist, 22(3): 269-287

Paronuzzi, P., M. Del Fabbro and P. Maddaleni. 2002. Frane superficiali tipo slide debris flow causate dal nubifragio del 21/22 giugno 1996 nella Val Chiarso` (Alpi Carniche, Friuli). Memorie della Societa Geologica Italiana 57: 443-452

Polloni, G., M. Ceriani, S. Lauzi, N. Padovan and G. Crosta. 1992 Rainfall and soil slipping events in Valtellina. Proceedings of the International Symposium on Landslides 1 , Christchurch, 183-188

Sanchez-Castillo, L., T. Kubota, I. Cantu-Silva and Hasnawir. 2015. Critical rainfall for the triggering of sediment related disasters under the urban forest development in Nuevo Leon, Mexico, Int. J. Ecol. Dev., 30(1): 1-10

Sandersen, F., S. Bakkehøi, E. Hestnes and K. Lied. 1996. The influence of meteorological factors on the initiation of debris flows, rockfalls, rockslides and rockmass stability. In: Senneset $\mathrm{K}$ (ed) Proceedings of the 7th International Symposium on Landslides, Trondheim, 97-114

Su, W.J and C. Stohr. 2000. Aerial-photointerpretation of landslides along the Ohio and Mississippi rivers. Environmental and Engineering Geoscience, 6(4): 311-323

Temesgen, B., M. U. Mohammed and T. Korme. 2001. Natural hazard assessment using GIS and remote sensing methods, with particular reference to the landslides in the Wondogenet area. Ethiopia Physics and Chemistry of the Earth, Part C: Solar, Terrestrial and Planetary Science, 26(9): 665-675

Van Beek, L. P. H and Th. W. J Van Asch. 2004. Regional assessment of the effects of land-use change on landslide hazard by means of physically based modelling. Natural Hazards, 31(1) 289-304

Wasowski, J., C. Lamanna and D. Casarano. 2010. Influence of land-use change and precipitation patterns on landslide activity in the Daunia Apennines, Italy, Q. J. Eng. Geol. Hydroge., 43: $387-401$

Wieczorek, G. F. 1987. Effect of rainfall intensity and duration on debris flows in central Santa Cruz Mountains, California. In Debris Flows/Avalanches: Processes, Recognition and Mitigation. Reviews in Engineering Geology 7, Costa JE, Wieczorek GF (eds). Geological Society of America: Colo, 23-104 